\title{
SISTEM PENDUKUNG KEPUTUSAN PENENTUAN PRIORITAS PEMBANGUNAN MENGGUNAKAN METODE PROMETHEE PADA DESA AYULA KECAMATAN RANDANGAN KABUPATEN POHUWATO PROVINSI GORONTALO
}

\author{
Jorry Karim \\ oyie.ptolot@gmail.com \\ STMIK Ichsan Gorontalo
}

\begin{abstract}
Abstrak
Permasalahan yang sering terjadi di desa yaitu tahap pembangunan didesa harus mempertimbangkan skala prioritas dan unsur keadilan, serta belum adanya Sistem Pendukung Keputusan untuk Penentuan Prioritas Pembangunan pada Desa Ayula Kecamatan Randangan dan juga sistem yang digunakan saat ini belum terkomputerisasi secara maksimal. Oleh karena itu, pada penelitian ini akan dirancang sebuah sistem pendukung keputusan untuk menentukan prioritas pembangunan.Metode yang digunakan adalah Metode MCDM digunakan untuk melakukan penilaian atau seleksi terhadap beberapa alternatif dalam jumlah terbatas. Salah satu metode penyelesaian masalah MCDM yaitu PROMETHEE yang merupakan salah satu metode penentuan urutan atau prioritas.Sistem inidirancang menggunakan bahasa Pemrograman PHP dengan Database MySQL, untuk membuatkan sebuah sistem pendukung keputusan baru yang berbasis komputerisasi yang merupakan salah satu alternatif yang baik dengan mengedepankan efektifitas dan efisien dalam Penentuan Prioritas Pembangunan.
\end{abstract}

Kata Kunci : Priorias, Pembangunan, Desa, PROMETHEE

\section{Pendahuluan}

Berdasarkan peraturan menteri desa, Pembangunan daerah tertinggal, dan transmigrasi Nomor 5 tahun 2015 Tentang Penetapan prioritas penggunaan dana desa tahun 2015. Dana Desa adalah dana yang bersumber dari Anggaran Pendapatan dan Belanja Negara yang diperuntukkan bagi Desa yang ditransfer melalui Anggaran Pendapatan dan Belanja Daerah kabupaten/kota dan digunakan untuk mendanai penyelenggaraan pemerintahan, pelaksanaan pembangunan, pembinaan kemasyarakatan, dan pemberdayaan masyarakat. [2].

Permasalahan yang sering terjadi di desa yaitu tahap pembangunan didesa harus mempertimbangkan skala prioritas dan unsur keadilan, serta belum adanya Sistem Pendukung Keputusan untuk Penentuan Prioritas Pembangunan pada Desa Ayula Kecamatan Randangan dan juga sistem yang digunakan saat ini belum terkomputerisasi secara maksimal. Oleh karena itu, pada penelitian ini akan dirancang sebuah sistem pendukung keputusan untuk menentukan prioritas pembangunan.

Metode yang digunakan dalam sistem pendukung keputusan ini adalah Metode MCDM digunakan untuk melakukan penilaian atau seleksi terhadap beberapa alternatif dalam jumlah terbatas. Secara umum dikatakan menyeleksi alternatif terbaik dari sejumlah alternatif yang ada. Salah satu metode penyelesaian masalah MCDM yaitu PROMETHEE (Preference Ranking Organization Method for Enrichment Evaluation) adalah salah satu metode penentuan urutan atau prioritas dalam MCDM (Multi Criterion Decision Making). Dugaan dari dominasi kriteria yang digunakan dalam PROMETHEE adalah penggunaan nilai dalam hubungan outranking. [1]

Untuk itu peneliti mencoba membuat Sistem Pendukung Keputusan dengan menggunakan Metode PROMETHEE dan bahasa Pemrograman PHP dengan Database MySQL, untuk membuatkan sebuah sistem pendukung keputusan baru yang berbasis komputerisasi yang merupakan salah satu alternatif yang baik dengan mengedepankan efektifitas dan efisien dalam Penentuan Prioritas Pembangunan dengan judul "Sistem Pendukung Keputusan Penentuan Prioritas Pembangunan Menggunakan Metode PROMETHEE Pada Desa Ayula Kecamatan Randangan". Peneliti membatasi masalah dalam penelitian ini hanya membahas tentang Penentuan Prioritas Pembangunan sesuai yang berlaku pada Desa Ayula dan berdasarkan kriteria Penentuan Prioritas Pembangunan Pada Desa Ayula. Penelitian ini bertujuan untuk Membangun sebuah Sistem Pendukung Keputusan Penentuan Prioritas Pembangunan Menggunakan Metode PROMETHEE yang terkomputerisasi untuk menggantikan sistem lama yang digunakan Desa Ayula Kecamatan Randangan. 
Berdasarkan Peraturan Menteri Dalam Negeri Nomor 66, Rencana Kerja Pembangunan Desa yang selanjutnya disingkat (RKP-Desa) adalah dokumen perencanaan untuk periode 1 (satu) tahun dan merupakan penjabaran dari RPJM-Desa yang memuat rancangan kerangka ekonomi desa, dengan mempertimbangkan kerangka pendanaan yang dimutahirkan, program prioritas pembangunan desa, rencana kerja dan pendanaan serta perkiraan maju, baik yang dilaksanakan langsung oleh pemerintah desa maupun yang ditempuh dengan mendorong partisipasi masyarakat dengan mengacu kepada Rencana Kerja Pemerintah Daerah dan RPJM-Desa. [3]

RKP Desa ditetapkan dengan Surat Keputusan (SK) Kepala Desa dan disusun melalui forum musyawarah perencanaan pembangunan (musrenbang) tahunan atau biasa disebut musrenbang Desa. Dokumen RKPDesa kemudian menjadi masukan (input) penyusunan dokumen APB Desa dengan sumber anggaran dari Alokasi Dana Desa (ADD), Pendapatan Asli Desa (PA Desa), swadaya dan pastisipasi masyarakat, serta sumber-sumber lainnya yang tidak mengikat.

Jenis-Jenis pembangunan desa seperti : Pengadaan Tenda untuk posyandu, Pembangunan Aula Kantor, Pembangunan Gedung TPA, Pengadaan Bahan Jamban, Pengadaan Panggung Kehormatan, Pengadaan jaringan listrik, dan pengadaan tempat parkir didesa.

Proses penyusunan dokumen RKP Desa dapat dibagi dalam tiga tahapan, tahapan tersebut adalah :

1. Tahap Persiapan Musrenbang Desa,

2. Tahap Pelaksanaan Musrenbang Desa

3. Tahap Sosialisasi

\section{Metode}

\subsection{Pengertian Sistem Pendukung Keputusan}

Sistem Pendukung Keputusan (SPK) merupakan aplikasi interaktif berbasis komputer yang mengkombinasikan data dan model matematis untuk membantu proses pengambilan keputusan dalam menangani suatu masalah.[5]

\subsection{MCDM (Multiple Criteria Decision Making)}

MCDM bertujuan memilih alternatif terbaik dari suatu set alternatif yang harus memenuhi beberapa tujuan yang telah memilki beberapa kriteria MCDM memiliki beberapa langkah proses: [6]

1. Membangun model untuk menjelaskan sistem testruktur, komponen, dan interaksi antar kriteria.

2. Definisi tujuan.

3. Spesifikasi kriteria yang relevan untuk mengidentifikasi tujuan diinginkan dan tidak diinginkan.

4. Menciptakan dan mengidentifikasi alternatif yang mungkin.

5. Mencoba alternatif pilihan yang ada, apakah sudah mampu memenuhi tujuan yang akan dicapai.

6. Menganalisa dampak alternatif pilihan yang ada.

7. Menimbang dan mengurutkan dari alternatif pilihan sesuai dengan preferensi pengambil keputusan

\subsection{PROMETHEE (Preference Ranking Organization Method for Enrichment Evaluation)}

PROMETHEE adalah satu dari beberapa metode penentuan urutan atau prioritas dalam analisis multikriteria. Metode ini dikenal sebagai metode yang efisien dan simple, tetapi juga yang mudah diterapkan dibanding dengan metode lain untuk menuntaskan masalah multikriteria. Metode ini mampu mengakomodir kriteria pemilihan yang bersifat kuantitatif dan kualitatif. Masalah utamanya adalah kesederhanaan, kejelasan dan kestabilan. Dugaan dari dominasi kriteria yang digunakan dalam PROMETHEEadalah penggunaan nilai dalam hubungan outranking.[4] Masalah pembuatan keputusan dengan multikriteria dapat dituliskan sebagai berikut :

$$
\operatorname{Max}\{\mathrm{fl}(\mathrm{a}), \mathrm{f2}(\mathrm{a}), \ldots, \mathrm{fk}(\mathrm{a}): \mathrm{a} \in \mathrm{A}
$$

Jika $A$ adalah set dari alternatif pilihan yang mungkin terjadi, $f 1, f 2, \ldots, f k$ adalah kriteria yang mana telah dievaluasi sebelumnya. Apabila semua kriteria memiliki tingkat kepentingan yang tidak sama, pembobotannya dapat ditandai dengan w1,w2, .., wk. 


\section{Jurnal IImiah ILKOM Volume 10 Nomor 1 April 2018}

PROMETHEEdapat dijelaskan dalam tiga tahapan :

1. Mengumpulkan semua struktur preferensi

Memaparkan kriteria yang dijadikan untuk mendapatkan pertimbangan dari rentang deviasi dalam penilaian sebuah altenatif dari tiap kriteria yang ada.

2. Mengumpulkan relasi yang dominan

Relasi outrangking dibuat sesuai dengan estimasi dari alternatif dari semua kriteria. Total tingkatan dari preferensi adalah suatu alternatif yang mana mendominasi dari hitungan untuk masing-masing pasangan alternatif yang lain.

3. Analisis keputusan

Metode PROMETHEEI memberikan sebuah peringkat sebagian dari set A.

Informasi akan alternatif yang tidak memiliki tandingan juga telah diberikan. Metode PROMETHEEII akan memberikan peringkat yang komplit dari set A. [4]

\section{Hasil dan Pembahasan}

\subsection{Langkah-Langkah Menjalankan Sistem}

Langkah-langkah menjalankan program yaitu dengan cara membuka browser dan memanggil website Sistem Pendukung Keputusan Penentuan Prioritas Pembangunan

\section{Tampilan Entry Data Kriteria}

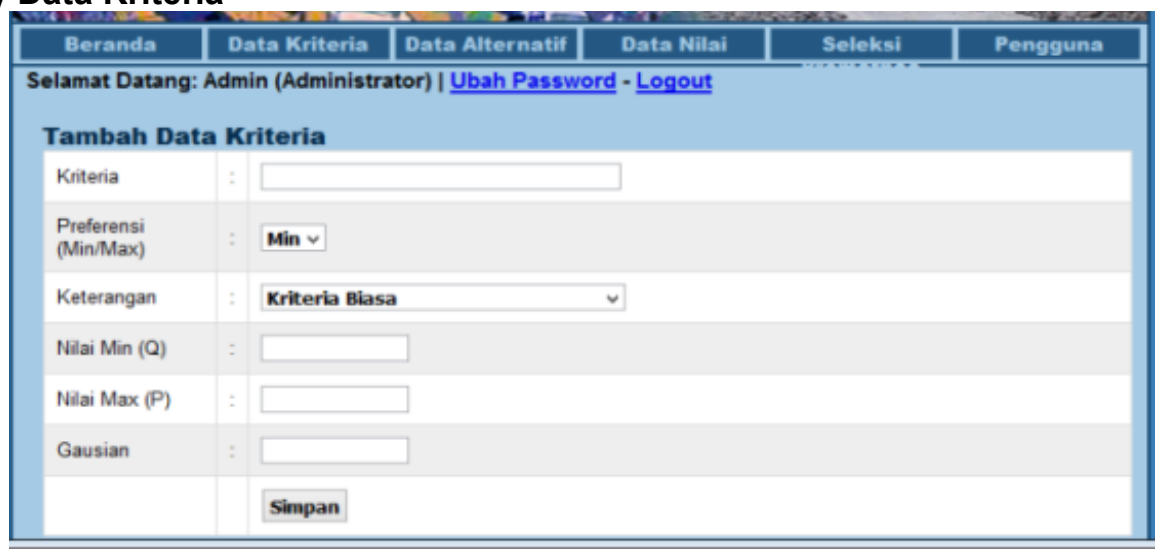

Gambar 1. Entry Data Kriteria

Pada form ini digunakan untuk memasukkan data Kriteria Penentuan Prioritas Pembangunan pada Desa Ayula Kecamatan Randangan.

\section{Tampilan Entry Data Kriteria Seleksi}

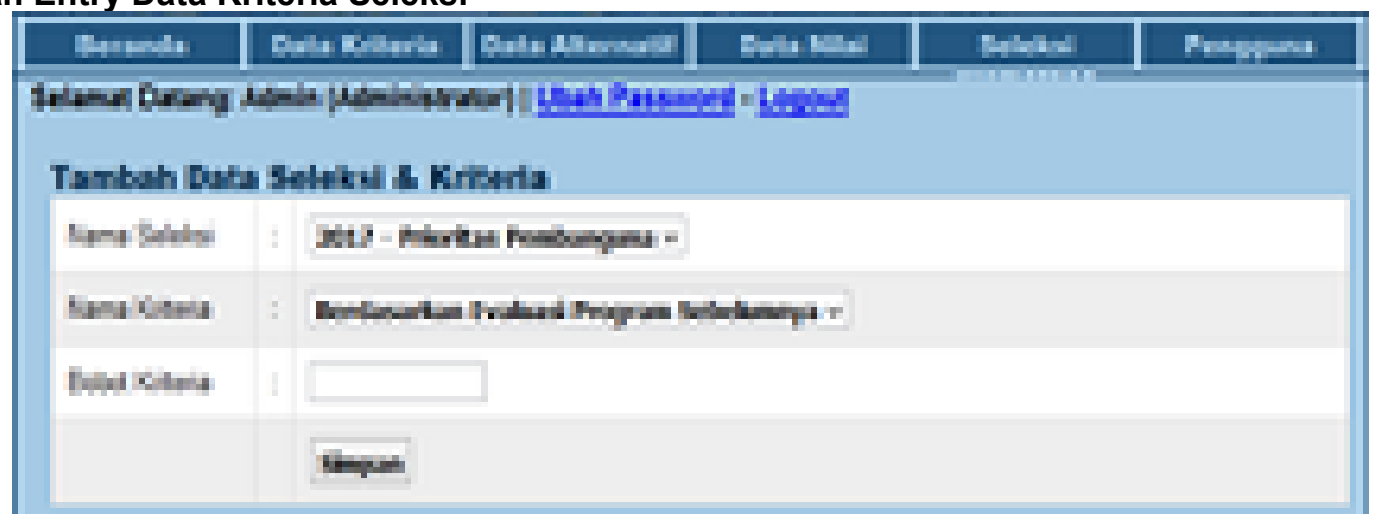

Gambar 2. Entry Data Kriteria Seleksi

Form ini digunakan untuk Menginput data-data kriteria seleksi yang akan digunakan dalam Penentuan Prioritas Pembangunan pada Desa Ayula Kecamatan Randangan. Untuk Menginput data pilih tombol tambah, kemudian isi data kriteria seleksi. Setelah data-data sudah terisi lengkap selanjutnya klik simpan untuk menyimpannya dalam sistem. 
Jurnal IImiah ILKOM Volume 10 Nomor 1 April 2018

Tampilan Entry Data Alternatif

\begin{tabular}{|c|c|c|c|c|c|c|}
\hline Prath & \multicolumn{2}{|c|}{ Britrinth } & Bumpard & Buth & Antra & Rasing \\
\hline \multicolumn{7}{|c|}{ 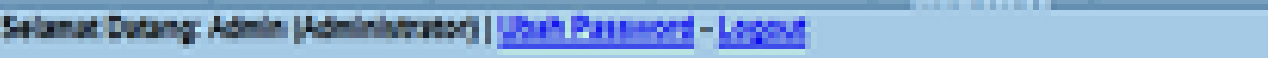 } \\
\hline \multicolumn{7}{|c|}{ Tansoh Butu Alrmal } \\
\hline the & & & & & & \\
\hline \multirow[t]{2}{*}{ 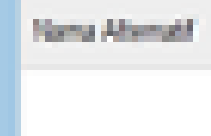 } & $=$ & & & & & \\
\hline & & 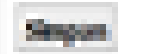 & & & & \\
\hline
\end{tabular}

Gambar 3. Entry Daftar Alternatif

Form ini digunakan untuk Menginput data-data alternatif yang akan digunakan dalam Penentuan Prioritas Pembangunan pada Desa Ayula Kecamatan Randangan. Untuk Menginput data pilih tombol tambah data, kemudian isi data bobot. Setelah data-data sudah terisi lengkap selanjutnya klik simpan untuk menyimpannya dalam sistem.

\section{Tampilan Entry Data Alternatif yang di Seleksi}

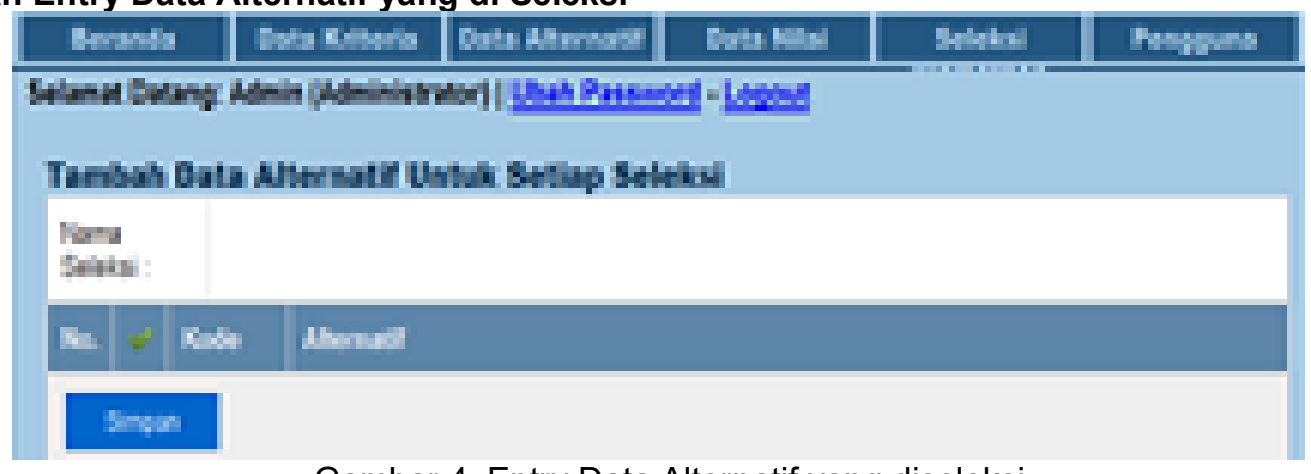

Gambar 4. Entry Data Alternatif yang diseleksi

Form ini digunakan untuk Memilih data-data alternatif yang telah dilnputkan pada form Daftar Alternatif yang akan digunakan dalam Penentuan Prioritas Pembangunan pada Desa Ayula Kecamatan Randangan. Untuk Menginput data pilih tombol tambah, kemudian cheklist data alternatif yang dipilih. Setelah data-data sudah terpilih selanjutnya klik simpan untuk menyimpannya dalam sistem.

\section{Tampilan Nilai}

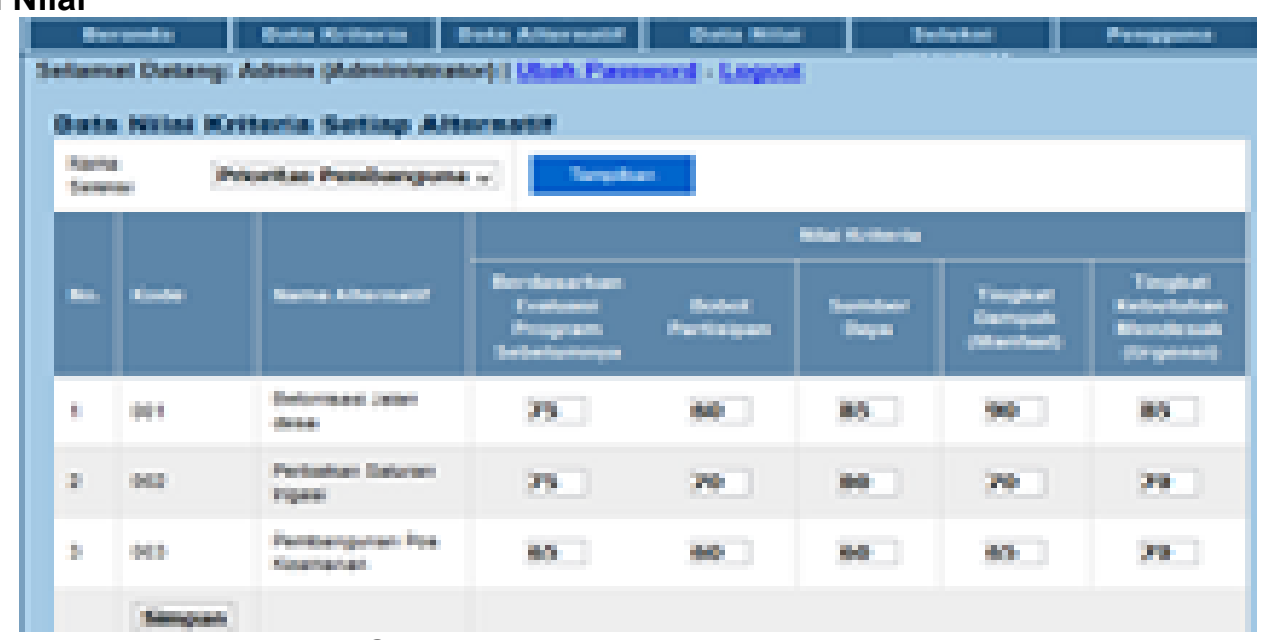

Gambar 5. Tampil data nilai kriteria

Pada form ini digunakan untuk mengisi nilai dari masing-masing alternatif berdasarkan kriteria Penentuan Prioritas Pembangunan. 


\section{Jurnal IImiah ILKOM Volume 10 Nomor 1 April 2018}

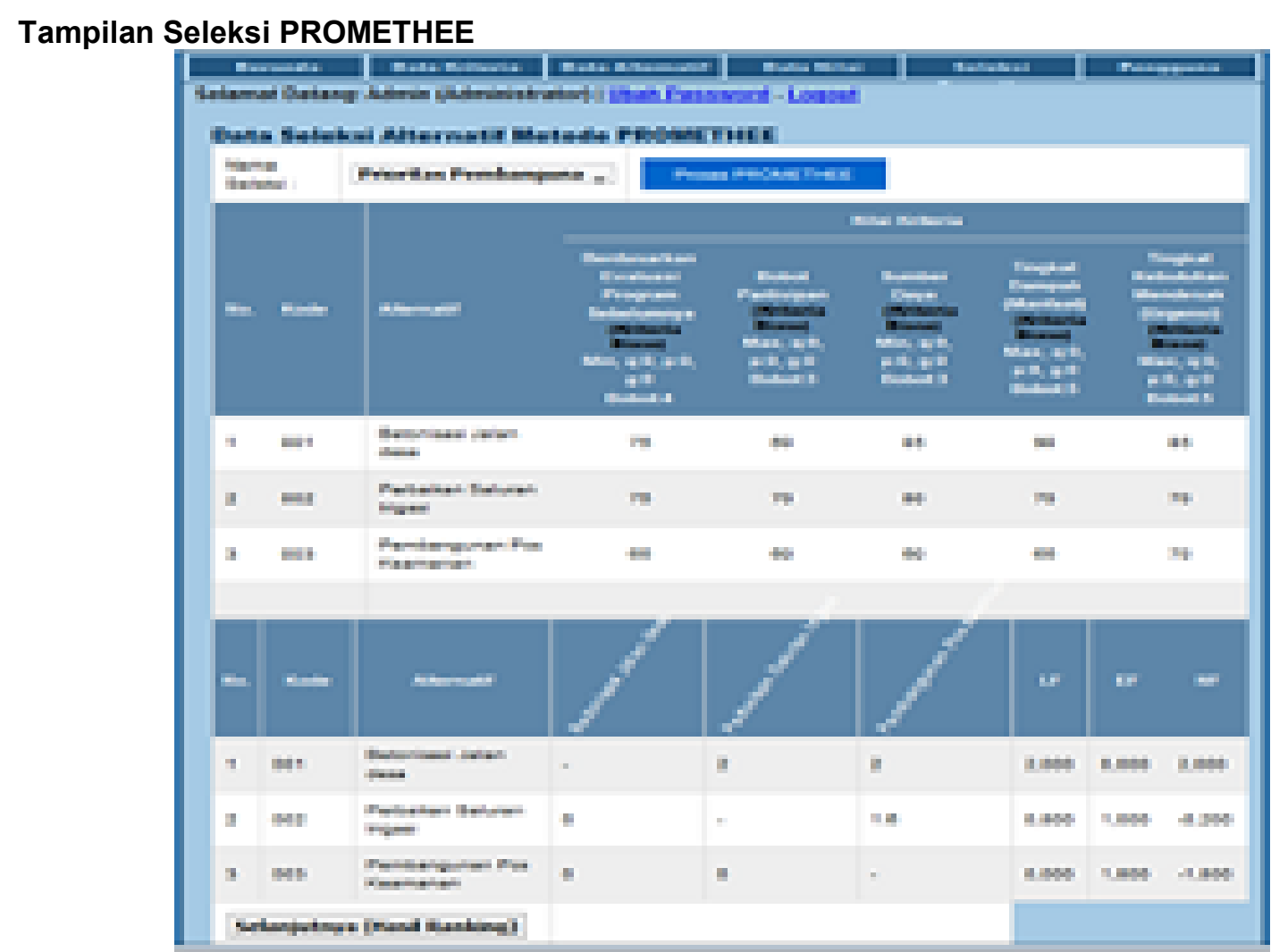

Gambar 6. Tampilan Seleksi PROMETHEE

Pada form ini digunakan untuk menentukan Nilai Keputusan Seleksi menggunakan metode PROMETHEE untuk Penentuan Prioritas Pembangunan berdasarkan penilaian yang terlebih dahulu diinputkan.

\section{Tampilan Laporan Hasil Rangking}

Hasil Ranking Berdasarkan PROMETHEE I

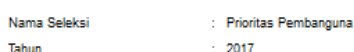

\begin{tabular}{|c|c|c|c|c|c|c|c|c|}
\hline No. & Kode & Nama Alternatif & LF & Rank & Kode & Nama Alternatif & EF & Rank \\
\hline 1 & 001 & Betonisasi Jalan desa & 2 & 1 & 001 & Betonisasi Jalan desa & 0 & 1 \\
\hline 2 & 002 & Perbaikan Saluuran lrigasi & 0.8 & 2 & 002 & Perbaikan Saluuran lrigasi & 1 & 2 \\
\hline 3 & 003 & Pembangunan Pos Keamanan & 10 & 3 & 003 & Pembangunan Pos Keamanan & 1.8 & 3 \\
\hline
\end{tabular}

Hasil Ranking Berdasarkan PROMETHEE II

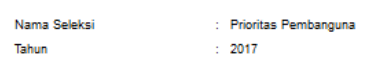

Alternatif dengan nilia Net Flow (NF) paling besar merupakan alternatif terbaik

\begin{tabular}{|c|c|c|c|c|}
\hline No. & NISN & Nama Lengkap & $\mathrm{NF}$ & Rank \\
\hline 1 & $\infty 01$ & Eetonisasi Jalan desa & 2 & 1 \\
\hline 3 & 003 & Pembangunan Pos Keamanan & -1.8 & 3 \\
\hline
\end{tabular}

Gambar 7. Laporan Hasil Rangking

Pada form ini, digunakan untuk menampilkan Hasil Perangkingan menggunakan Metode PROMETHEE untuk Penentuan Prioritas Pembangunan pada Desa Ayula Kecamatan Randangan.

\section{Kesimpulan dan Saran}

\subsection{Kesimpulan}

Berdasarkan hasil penelitian maka dapat ditarik kesimpulan sebagai berikut:

1. Sistem yang digunakan mampu melakukan seleksi pembangunan desa berdasarkan skala prioritas dari hasil perengkingan

2. Penerapan Metode PROMETHEE untuk sistem pendukung keputusan dapat memberikan hasil yang maksimal dalam hal pengambilan keputusan penentuan prioritas pembangunan desa. 


\subsection{Saran}

Adapun saran untuk penyempurnaan penelitian ini adalah :

1. Untuk pengembangan penelitian lebih lanjut maka sebaiknya dilakukan perbandingan metode atau penggabungan metode.

2. Kriteria penilaian yang digunakan harus mengacu pada aturan yang telah ditetapkan di Desa setempat

\section{Daftar Pustaka}

[1] Kahraman, C. 2008. Fuzzy Multi Chriteria Decision Making. New York: Springer

[2] Peraturan Menteri Desa, Pembangunan Daerah Tertinggal, Dan Transmigrasi Nomor 5 Tahun 2015 Tentang Penetapan Prioritas Penggunaan Desa.(http://ensiklo.com/2015/03/16/permendes-no-5-tahun-2015-tentang-penetapan-prioritaspenggunaan-dana-desa/ diakses tanggal 3 Oktober 2017)

[3] Peraturan Menteri Dalam Negeri Nomor 66 Tahun 2007 Tentang Perencanaan Pembangunan Desa. (http://binapemdes.kemendagri.go.id / diakses tanggal 3 Oktober 2017)

[4] Prabowo, Fahroni Hadi. 2007. Penerapan Metode Promethee dalam Menentukan Prioritas Pinjaman Kredit Pemilikan Rumah (KPR IB) Kepada Nasabah Debitur (Studi Kasus Bank Brisyariah Cabang Sidoarjo). Surabaya: Sekolah Tinggi Manajemen Informatika \& Teknik Komputer

[5] V ercellis, Carlo. 2009. Business Intelligence: Datamining and Optimization For Decision Making. Chichester : Jhon Wiley \& Sons

[6] Ziller, Annette et al. 2008. Multi Criteria Decision Making. (http://ppta.stikom.edu/upload/upload/file/ 04410100017Makalah.pdf / diakses tanggal 3 Oktober 2017) 